\title{
GLL
}

Geomatics, Landmanagement and Landscape No. $1 \bullet 2019,7-14$

\section{A COMPARATIVE ANALYSIS OF REAL ESTATE PROPERTY MARKETS IN THE CITIES OF CIESZYN AND ČESKÝ TĚŠÍN}

\author{
Agnieszka Bitner, Urszula Litwin, Wiktoria Biłko
}

\begin{abstract}
Summary
The article presents a comparative analysis of real estate markets in the cities of Cieszyn and Český Těśn. For almost 100 years these two cities have been divided by interstate borders, currently between Poland and the Czech Republic. Previously, they constituted one city. Due to the difficulties in obtaining transactional data from Český Těšín, the analysis was carried out for real estate properties offered on the market. The research covered real estate developed with singlefamily houses and undeveloped land designated for development. The analysis showed that in terms of real estate prices, Český Těšín is more attractive for a potential buyer.
\end{abstract}

\section{Keywords}

real estate market analysis • Cieszyn • Český Těšín

\section{Introduction}

When examining the local real estate market, we usually limit ourselves to analysing real estate located in a given town or municipality. There are many examples of that in the literature on the subject [Siejka 2011, Całka and Bielecka 2014, Bitner et al. 2017]. For centuries, the cities of Cieszyn and Český Těšn constituted one urban organism, which at the beginning of the twentieth century was artificially divided between two countries into two separate towns. Since then, other factors affecting the current condition of real estate markets in both towns have influenced the two parts of the city, divided by an interstate border. These two cities currently have two different cadastral systems [Wilkowski et al. 2006, Leń et al. 2015, Janečka and Souček 2017]. The article presents a comparative analysis of the current condition of real estate markets in the cities of Cieszyn and Český Těśín. The comparative analysis was carried out using the methods of descriptive statistics.

The area of research is determined by the administrative boundaries of the neighbouring cities of Cieszyn and Český Těšín. These two towns, located on either side of the Olza River - in Poland and the Czech Republic, respectively - used to constitute one city, located on the Polish side. The city received its town charter in the thirteenth 
century. After the end of the First World War, Cieszyn and the entire Cieszyn Silesia became a conflict area, disputed between Poland and Czechoslovakia. At the beginning of 1919, the Czech army entered the area of Cieszyn Silesia. The dispute was resolved in 1920, when Cieszyn Silesia was divided between the two countries. The border was marked by the Olza River, dividing the city of Cieszyn into two parts (Fig. 1, Fig. 2). The first part, the historical one, remained within Poland, while the second, industrial one with the railway station, the mines and the nearby Třinec Iron and Steel Works was assigned to Czechoslovakia. As a result of this unfortunate division, the city on the Polish side ceased to develop [Zenderowski 2002, Ondřeka and Badurová 2010]. Currently, Cieszyn is a commercial, service and cultural centre. It is a popular tourist destination. One of the major attractions of the city is the picturesque market (Fig. 3) and the Castle Hill with a Romanesque Rotunda of Saint Nicholas, built in the eleventh century.

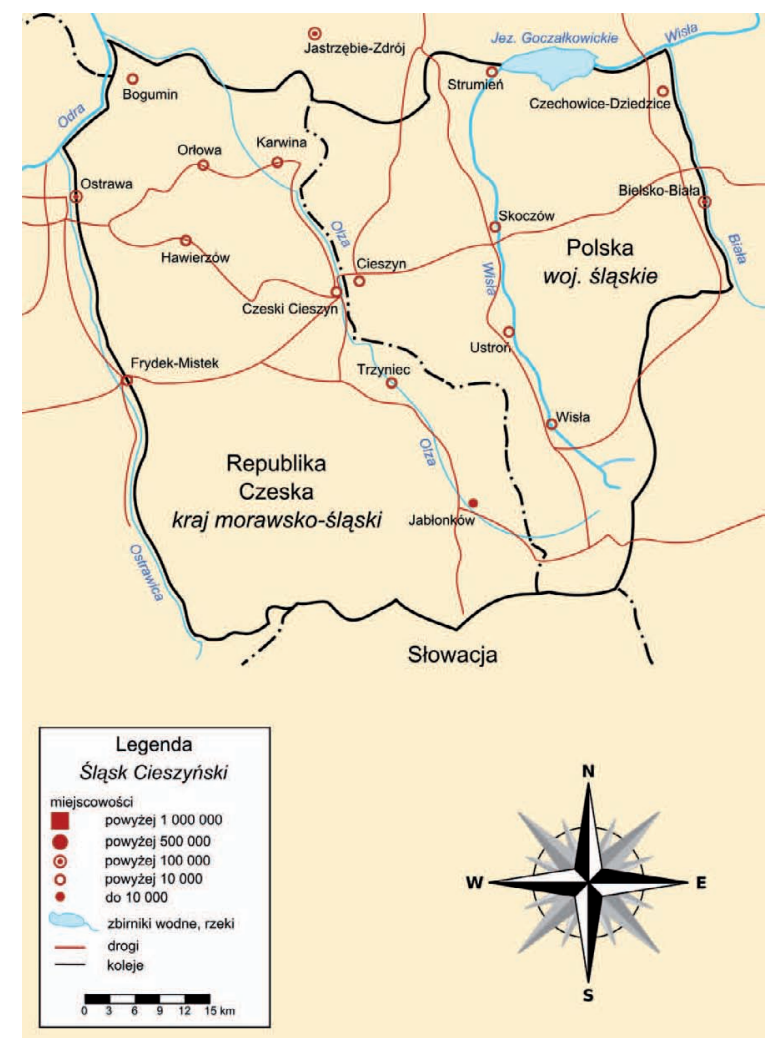

Source: https://pl.wikipedia.org/wiki/Śląsk_Cieszyński

Fig. 1. The map of Cieszyn Silesia with the border (marked with a dotted line) between Poland and the Czech Republic. In the central part of the map there are two border cities of Cieszyn and Český Těšín, separated in 1920 by an interstate border designated along the Olza River 


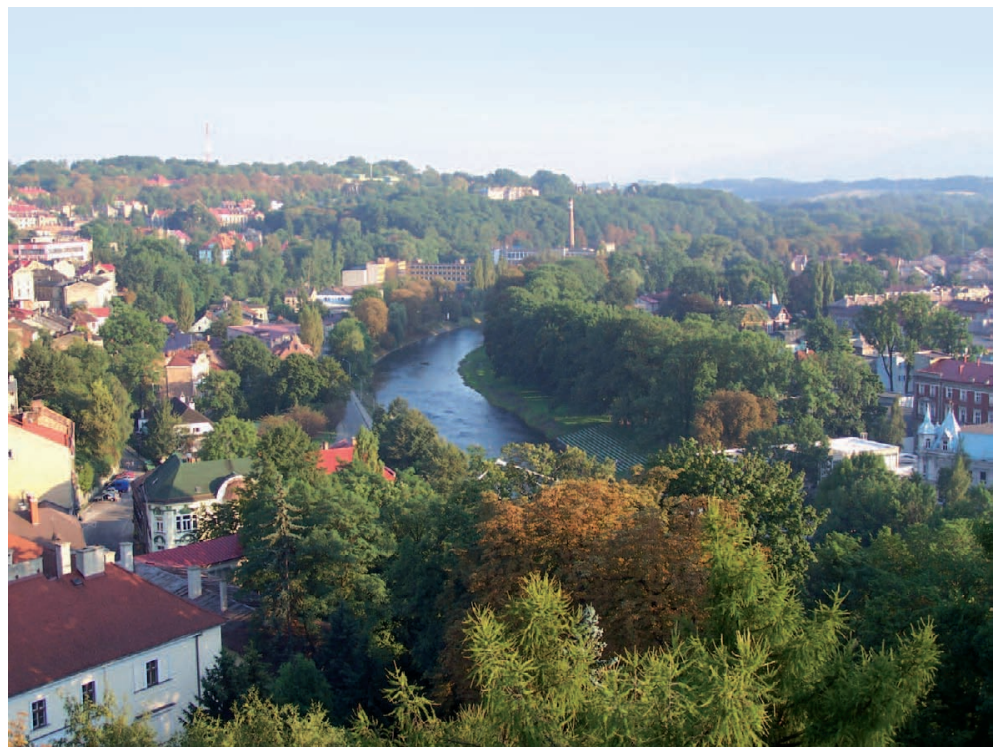

Source: https://commons.wikimedia.org/wiki/File:Ciesz_olza_czciesz_355.jpg (C BY-SA 3.0 pl)

Fig. 2. A photo of two border towns divided by the Olza river: Cieszyn on the left, Český Těšín on the right side of the photo
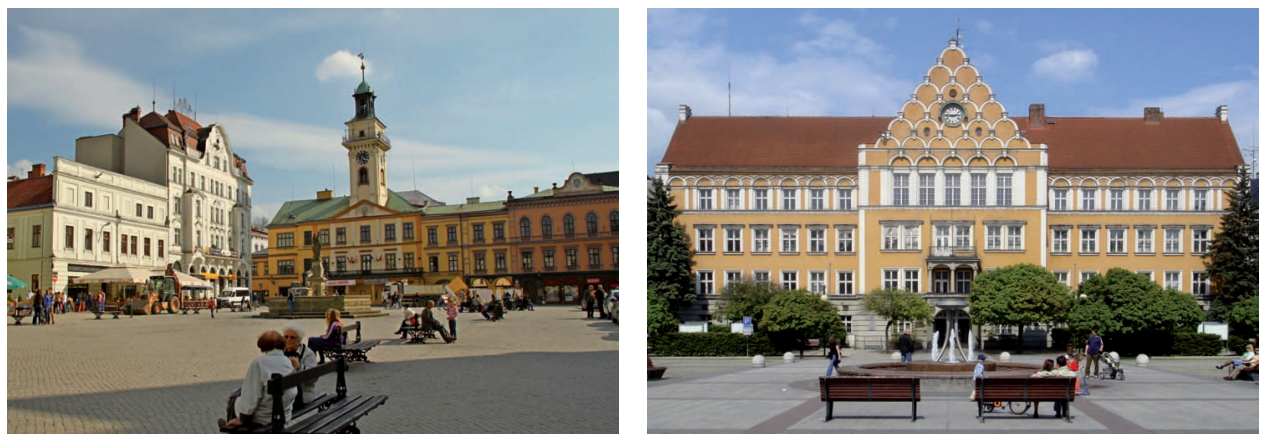

Source: https://pl.wikipedia.org/wiki/Cieszyn\#/media/File:Cieszyn_Rynek2.jpg (C BY-SA 3.0 pl) https://pl.wiki-pedia.org/wiki/Czeski_Cieszyn\#/media/File:Radnice_v_Českém_Těšíně.jpg (C BY-SA 3.0 pl)

Fig. 3. Town hall at the market square in Cieszyn (photo on the left) and town hall in Český Těšín (photo on the right)

\section{The database}

The analysis of real estate markets in the two cities - Cieszyn and Český Těšín - was carried out using data from the offers of real estate properties for sale, located in the central parts of both cities. The process of acquiring data on the Polish side of the city 
of Cieszyn city was different than the corresponding process on the Czech side. No records of land and buildings are kept in the Czech Republic, and therefore the only available data is the one contained in the real estate cadastre. The town hall in Český Těšín does not collect data on real estate transactions. For that reason, the prices as per the offers for the sale of real estate properties were adopted for the purpose of our market analysis. In Český Těšín, the data was provided by the following agencies: Slezská realitní agentura Česky Těšín s.r.o., Realty.cz (one of the most famous real estate offices in this market), and Re-max Czech Republic. For Cieszyn, the database was obtained from the websites of real estate agencies.

The database includes properties similar in terms of price-forming characteristics. A total of 133 properties on offer were adopted for the analysis of the real estate market. 73 properties were inspected in Cieszyn, including 33 undeveloped land plots designated for development, and 40 properties developed with single-family houses. 60 real estate properties were analysed in Český Těšín, of which 30 are undeveloped land plots, designated for development, and 30 are developed with single-family houses. The properties adopted for the analysis of a given type of property share similar attributes. There are definitely more offers available in the Polish Cieszyn than in the Český Těšín, especially in the case of land developed with single-family houses.

The research covered transactions from the period from November 1, 2017 to April 1, 2014. Offer prices on the Czech side were expressed in Czech korunas, therefore they were converted into Polish zloty according to the exchange rate of 01.04.2018. At that time, one Czech koruna converted to 0.1656 Polish zloty.

\section{Description and analysis of local real estate markets on either side of the Olza river}

When examining the characteristics of the contemporary cities of Cieszyn and Český Těšín, we clearly see that they once constituted one town. The historical part of the city remains on the Polish side, while the industrial part with the railway station is on the Czech side - which is why rail transport in the Polish Cieszyn is not as developed as on the Czech side. On a daily basis, residents of this city use public transport and private transport companies. In Český Těšín, the railway infrastructure is very well developed, and the vicinity of the Bohumín railway junction facilitates an easy and fast transport from this city by rail. In the vicinity of Český Těsín, Třinec Iron and Steel Works are located: one of the oldest metallurgical plants and one of the most profitable enterprises in the Czech Republic. The steelworks is a vast complex of foundries, steel mills, rolling mills, coking plants and machine production. The plant employs a significant percentage of the inhabitants of Český Těšín. Unfortunately, it also has a negative impact on the natural environment. The air condition in the Trinec region is bad all year round.

According to data obtained from the Local Data Bank, in 2016, the city of Cieszyn was inhabited by 35102 people. According to data from the Czech Statistical Office, 24650 people lived in Český Těšín in 2016. This is about 10 thousand less inhabitants than the Polish side. 
A comparative analysis of real estate markets [Hoxha and Temeljotov-Salaj 2014] began with the examination of offered properties - land developed with single-family houses. The basic property feature, which is the area size of the real estate property, has been examined. The table below presents a list of basic statistical measures describing the areas of land plots and houses standing on them.

Table 1. Offered real estate properties developed with single-family houses. Summary statistics describing the areas of land plots and houses

\begin{tabular}{|l|c|c|c|c|}
\hline Measures & $\begin{array}{c}\text { Cieszyn } \\
\text { Area of land plots } \\
\text { [sq. m] }\end{array}$ & $\begin{array}{c}\text { Český Tešín } \\
\text { Area of land plots } \\
\text { [sq. m] }\end{array}$ & $\begin{array}{c}\text { Cieszyn } \\
\text { Area of houses } \\
\text { [sq. m] }\end{array}$ & $\begin{array}{c}\text { Český Těšín } \\
\text { Area of houses } \\
{[\text { sq. m] }}\end{array}$ \\
\hline Mean & $1329 \pm 150$ & $1239 \pm 257$ & $169 \pm 9$ & $207 \pm 16$ \\
\hline Median & 1000 & 750 & 160 & 220 \\
\hline Mode & 1000 & 750 & 130 & 220 \\
\hline Minimum & 100 & 154 & 80 & 80 \\
\hline Maximum & 3862 & 7270 & 370 & 400 \\
\hline
\end{tabular}

Source: authors'study

Table 1 shows that in Cieszyn offered properties built-up with single-family houses had larger land plot areas and smaller house areas compared to the same type of real estate in Český Těšín. This is evidenced by the values of three basic statistics: mean, median and mode. Real estate offer prices were more varied on the Czech side.

Another important feature of real estate developed with single-family houses is the technical condition of the residential buildings. The analysed databases contained a good description of the technical condition of the buildings. On this basis, the real estate properties were divided into five groups due to the technical condition of the house. The number of properties with building shells is comparable on both sides of the Olza river. It accounts for about $7.5 \%$ of all properties included in the analysis. Another group consists of real estate developed with houses in very good condition, i.e. such that does not require any financial outlays for repairs, with the house having high standard equipment. On the Polish side, these properties represent as much as $30 \%$, whereas on the Czech side, they account for $17 \%$, which is significantly less, by almost half. The ratio is similar between the number of houses in good condition, whose percentage share is $20 \%$ and $10 \%$, respectively. Houses in a medium technical condition, with low standard equipment and requiring renovation work, constitute $30 \%$ and $50 \%$, respectively. The technical condition was poor in 13\% of all buildings in Cieszyn and in $17 \%$ of all buildings in Český Těšín. To sum up, on the Polish side of the city, the houses were better maintained, and in a better technical condition than on the Czech side.

The prices of the offered real estate properties developed with single-family houses remained at a similar level in both cities. The average offer price was PLN 423000 for 
the entire property. The offered prices for the developed properties in Cieszyn ranged from PLN 159000 to PLN 770 000, whereas in Český Těšín, they ranged from PLN 165600 to PLN 910800.

The second group of real estate offers subjected to comparison were undeveloped land plots, designated for development. The studied data encompassed the same period as for properties built-up with single-family houses - that is from November 1, 2017 to April 1, 2018. The analysis was based on real estate properties that were located in the very centre - both on the Polish and on the Czech side of the border. Their distance from the centre was up to five kilometres. Table 2 contains basic statistics describing the area and unit prices of real estate properties put up for sale.

Table 2. Offered properties - undeveloped land plots, designated for development

\begin{tabular}{|l|c|c|c|c|}
\hline Measures & $\begin{array}{c}\text { Cieszyn } \\
\text { Area of land plots } \\
\text { [sq. m] }\end{array}$ & $\begin{array}{c}\text { Český Těśín } \\
\text { Area of land plots } \\
\text { [sq. m] }\end{array}$ & $\begin{array}{c}\text { Cieszyn } \\
\text { Offer prices } \\
\text { [PLN per sq. m] }\end{array}$ & $\begin{array}{c}\text { Český Těšín } \\
\text { Offer prices } \\
\text { [PLN per sq. m] }\end{array}$ \\
\hline Mean & $1589 \pm 97$ & $2174 \pm 298$ & $79 \pm 5$ & $60 \pm 5$ \\
\hline Median & 1500 & 1658 & 79 & 58 \\
\hline Mode & 1500 & 1284 & 100 & 72 \\
\hline Minimum & 830 & 450 & 38 & 17 \\
\hline Maximum & 3400 & 7510 & 140 & 136 \\
\hline
\end{tabular}

Source: authors' study

Table 2 shows that in Cieszyn, undeveloped plots with smaller areas than in Český Těšín were offered. The average area of plots in these cities varies by $584 \mathrm{~m} 2$. In the Czech part of the city, there are a greater variety of plots in terms of size. Unit prices of plots are higher on the Polish side by approximately $30 \%$ on average. The above analysis shows that it is more profitable to buy a development-designated plot on the Czech side of the city [Kazimoto 2016]. Also, in the Czech Republic, the procedure related to obtaining construction permits is simpler.

\section{Conclusions}

The paper presented a comparative analysis of two local real estate markets, in the cities of Cieszyn and Český Těšín. These markets are located on two sides of the river Olza, in a city that for centuries constituted one single urban organism. Almost 100 years ago, the city was divided along the Olza River - between Poland and Czechoslovakia (now the Czech Republic). Poland has been allocated the historical part of the city, whereas the industrial part along with the railway station remained on the Czech side.

The analysis of the two real estate markets located in the divided city showed the differences that exist in the offered real estate properties built-up with single-family 
houses as well as undeveloped real estate (land designated for development). Singlefamily houses put up for sale on the Polish side of the city were maintained in a better technical condition than those on the Czech side. The unit prices of land plots designated for development are more expensive by about $30 \%$ on the Polish side of the city. Taking into account the prices of real estate, Český Těšín is more attractive for a potential buyer.

\section{References}

Bitner A., Litwin U., Michalczewska A. 2017. Wykorzystanie metod kartograficznych i statystycznych w analizie lokalnego rynku nieruchomości w mieście Rabka-Zdrój. GLL, 1, 7-15.

Całka B., Bielecka E. 2014. Mapa średnich cen transakcyjnych mieszkań: studium przypadku pierwotnego rynku nieruchomości w Siedlcach. Roczniki Geomatyki, XII, 4(66), 379-387.

Hoxha V., Temeljotov-Salaj A. 2014. Fundamental Economic Factors that Affect Housing Prices: Comparative Analysis between Kosovo and Slovenia. Management, 9(4), 323-348.

Janečka K., Souček P. 2017. A Country Profile of the Czech Republic Based on an LADM for the Development of 3D Cadastre. ISPRS International Journal of Geo-Information, 6(5), 143, https://doi.org/10.3390/ijgi6050143

Kazimoto P. 2016. Challenges facing Real Estate Investment and Economic Growth International Journal of Research in IT, Management and Engineering, 6.

Leń P., Mika M., Oleniacz G., Bielska A., Dawid L., Deska K., Trembecka A. 2015. Wybrane zagadnienia z zakresu funkcjonowania katastru w Polsce. Współczesne problemy i trendy. Wydawnictwo Uniwersytetu Rolniczego w Krakowie, Kraków.

Ondřeka Z., Badurová P. 2010. Český Těšín. Příběh města na levém břehu řeky. Czeski Cieszyn. Historia miasta na lewym brzegu rzeki, Wart.

Siejka M. 2011. Analiza rynku nieruchomości rolnych na przykładzie wiejskich gmin powiatu krakowskiego. Infrastructure and Ecology of Rural Areas, 3, 265-273.

Wilkowski W., Budzyński T., Sobolewska-Mikulska K., Pułecka A. 2006. Współczesne problemy katastru i gospodarki nieruchomościami. Oficyna Wydawnicza Politechniki Warszawskiej, Warszawa.

Zenderowski R. 2002. Stosunki między mieszkańcami miast podzielonych granicą państwową na przykładzie Cieszyna i Czeskiego Cieszyna, http://www.studreg.uw.edu.pl/pdf/Sril08/3_ zender.pdf

Dr hab. inż. Agnieszka Bitner

Uniwersytet Rolniczy w Krakowie

Katedra Geodezji Rolnej, Katastru i Fotogrametrii

30-149 Kraków, ul. Balicka 253a

e-mail: rmbitner@cyf-kr.edu.pl

Prof. dr hab. inż. Urszula Litwin

Uniwersytet Rolniczy w Krakowie

Katedra Geodezji Rolnej, Katastru i Fotogrametrii

30-149 Kraków, ul. Balicka 253a

e-mail: urszulalitwin@wp.pl 
Mgr inż. Wiktoria Biłko

absolwentka Uniwersytetu Rolniczego w Krakowie

Wydział Inżynierii Środowiska i Geodezji

e-mail: wiktoriabilko14@gmail.com 